\title{
Increase of breeding capacity of sows of Wales breed
}

\author{
O. Zhukorskyi, \\ doctor of agrarian sciences, corresponding member of NAAS \\ National Academy of agrarian sciences of Ukraine, \\ O. Tsereniuk, \\ O. Akimov, \\ candidates of agrarian sciences \\ Institute of animal science NAAS
}

The purpose. To estimate the level of breeding capacity of sows of Wales breed in comparison with other breeds and its place in swine breeding according to basic localization in view of preliminary work on increase of genetic potential of productivity by complex of attributes. Methods. Results are given of selection-breeding work in swine breeding of Kharkov oblast. Genetic potential and degree of its realization is calculated. Results. Outcomes of work on increase of the level of genetic potential of productivity of sows of Wales breed are brought. Analysis of modern state of breed is carried out. Place of the breed in swine breeding on its basic localization is specified. The part of the breed in pedigree facilities of Kharkov oblast makes $62,5 \%$ of general livestock. The level of breeding capacity of sows is estimated and values of SIVJS index are calculated. Conclusions. Use in selection process of the developed methods of selection has provided increase of the level of breeding capacity of sows of domestic population of Wales breed. That in the further will reflect in status of the breed on its basic localization in Ukraine.

Key words: pigs, Wales breed, breeding capacity, subject of breeding business, genetic potential.

Responding to market needs pig industry of Ukraine is dynamically modified. Accordingly, for the production of more high-quality products there are positive changes to improve conditions of housing and feeding, new animal populations are formed - both through the use of imported and domestic breeds, types and lines of pigs. The main goal of this process is a steady increase in the genetic potential and the degree of its realization in key traits of pigs, providing not only popularization of the national gene pool, but also to increase its competitiveness in the market of breeding products. Therefore, the establishment and improvement of breeds of pigs is characterized by changing selection directions by productivity as social order and changing the genetic variability with spreading genealogical structure, crosses of lines and types in the purebred breeding, "updating" the blood through the source breeds in optimal environmental conditions with regard to specialization of breeds, complex evaluation of boars and sows with the economic approach to the term of their use [1-3].

Potential opportunities for realization of the genetic potential of productivity of source breeds of pigs are not yet fully achieved for most industrial pig breeds in Ukraine [4]. Wales breed of pigs is not exception. Animals of this breed are resembling both in appearance, and the type and level of performance to Landrace [5]. However, compared to Landrace, Wales is an alternative source of genetic information, they can be used in various systems of crossbreeding and hybridization as parental forms in combination with Large White breed and with Landrace. The level of reproductive capacity of sows of Welsh breed can also be successfully used it as the parent form [2]. Therefore, further increasing reproductive capacity of dams of Welsh breed is actual direction for both scientific research and practical work with the breed.

The object of the research - to assess the level of reproductive capacity of dams of Welsh breed compared to other breeds and its place in pig breeding for the main localization (Kharkiv region with considering previously carried out work to increase the genetic potential in productivity for complex traits that determine it. 
Material and methods of the research. The analysis of genetic potential of increasing productivity of reproductive capacity of sows of Welsh breed in the new factory line 933 Ted (created on the purebred basis) and UNI 562 family in the Wales breed (created on the crossbred basis using ancestor - dam Vorskla Poltava meaty breed 562 ). Assessment of these genealogical structural formations in the process of creation was done in the base farm by comparing to most numerous family in the breed (Like Girl).

The genetic potential (GP) of different performance traits was determined by the method of M.Z. Basovsky [6] as presented by V. Kovalenko, T.I. Nezhlukchenko [7] based on the conditional blood shares of source genotypes. The degree of realization of genetic potential (DRGP) was determined by the ratio of the actual performance to the theoretically calculated (in \%).

The results of breeding work in breeding pig husbandry in the Kharkiv region (according to appraisal reports on the subjects of breeding) were assessed. Selection Index of reproductive capacity (reproductive properties) of sows (SIRQS) (Tserenyuk AM, 2010) [8-9].

The results of the research were processed by the method of variation statistics [10-11].

The results of the research. At the preliminary stage the new lines and dam families of sows were formed based on the author's way of increasing the genetic potential based on involvement developed methods of selection into the selection process $([9,12])$. In view of the work on the formation, the analysis of the increase of the genetic potential of productivity of sow reproductive capacity on new genealogical structural formation in Wales breed. It was established that dams inseminated by boars Ted 933 line had better prolificacy (the difference is not significant) than contemporaries Gurley family and exceeded by weight at litter weaning pigs of the same family by $2.85-3.08 \%(p<0.01)$. Similar results were observed for this trait in dams of the family UNI 562, compared to dams of Gurley family their advantages in creating a family were $3.9 \%(p<0.01)$ and $4.5 \%(p<0.001)$. Higher level of reproductive capacity was manifested in increasing index values SIRQS in animals of new factory lines and families.

In generations sows inseminated by boars of Ted 933 line there was increasing genetic potential in prolificacy andlitter weight at weaning. However, the degree of realization of genetic potential in generations decreased. For example, in prolificacy of dams, inseminated by Ted 933 line of different generations, decrease was $8.55 \%$, in litter weight at weaning $-6.4 \%$, respectively.

In dams of UNI 562 family also there was increase of genetic potential in reproductive capacity in generations; however, compared to sows inseminated by boars of Ted 933 line, the difference between the generations in both prolificacy and litter weight at weaning was lower.

The degree of realization of the genetic potential of dams in the UNI 562 family in generations also declined, but to a lesser extent. As to prolificacy between generations in UNI 562 family - by $2.84 \%$ and in litter weight at weaning - by $2,82 \%$.

To date, both Ted 933 line and UNI 562 dam family are included to the rotary mating in both breeding farms of the Welsh pig breed and what in several generations was reflected in higher levels of reproductive capacity in the population as whole. Also, there were significant changes in the structure of the gene pool in the basic localization of Welsh breed in Ukraine.

In breeding farms of the Kharkiv region today operate four subjects with breeding pigs. Of these two subjects for Welsh breed, one for Landrace breed and one for Ukrainian meaty breed. Accordingly, the number of Welsh breed sows in the breeding subjects in the Kharkiv region exceeds the total number of breeds on the other (Ukrainian meaty and Landrace) and is $62.5 \%$ of the total number of sows in breeding farms of the area (Fig. 1). 


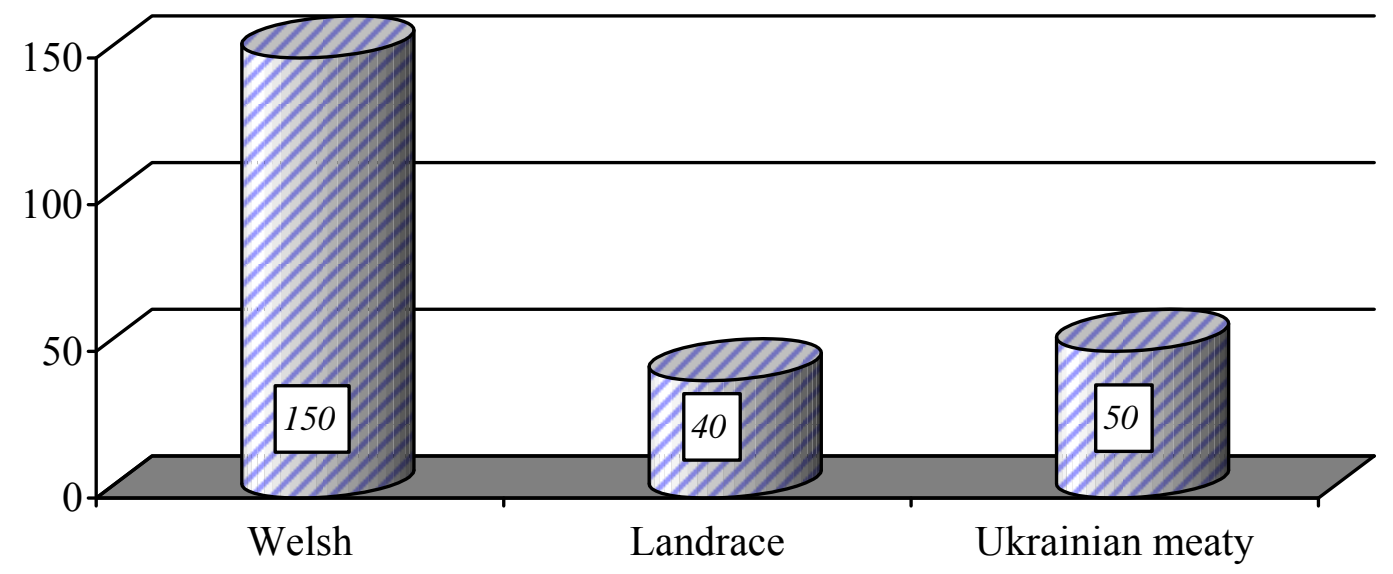

$\square$ Number of base sows, head

Fig. 1. The total number of sows in breeding farms of the Kharkiv region

As to the the average prolificacy uterus in different breeds advantage of Welsh compared to Landrace is 1.3 pig and compared to Ukrainian meaty 1.2 pig (Fig. 2).

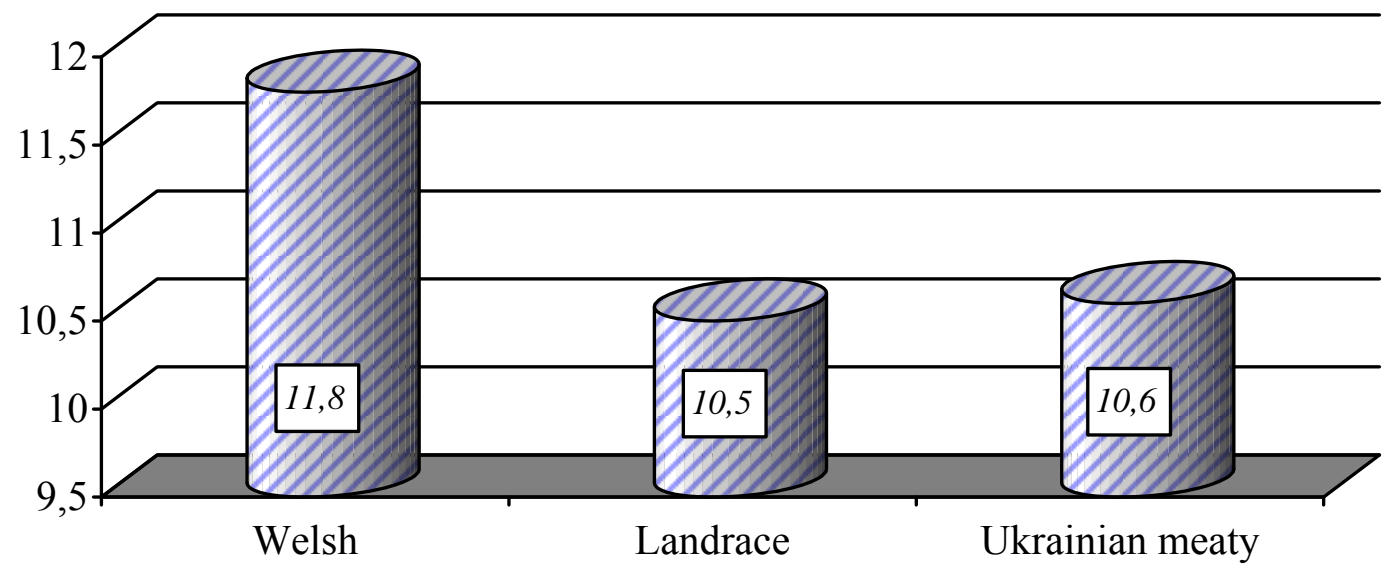

$\square$ Prolificacy of all dams by breeds in breeding farms in Kharkiv region

Fig. 2. Prolificacy for all sows by breeds in breeding farms in Kharkiv region

If as to the prolificacy there is obvious advantage of Welsh breed compared to Landrace and Ukrainian meaty, thenfor litter weight at weaning (in terms of 45-day) the difference between sows of Landrace and Welsh breed is negligible (Fig. 3). However, dams of Ukrainian meaty breed are inferior for this trait as to Welsh (by $8.58 \%$ ) and Landrace (by $7.86 \%$ ). 


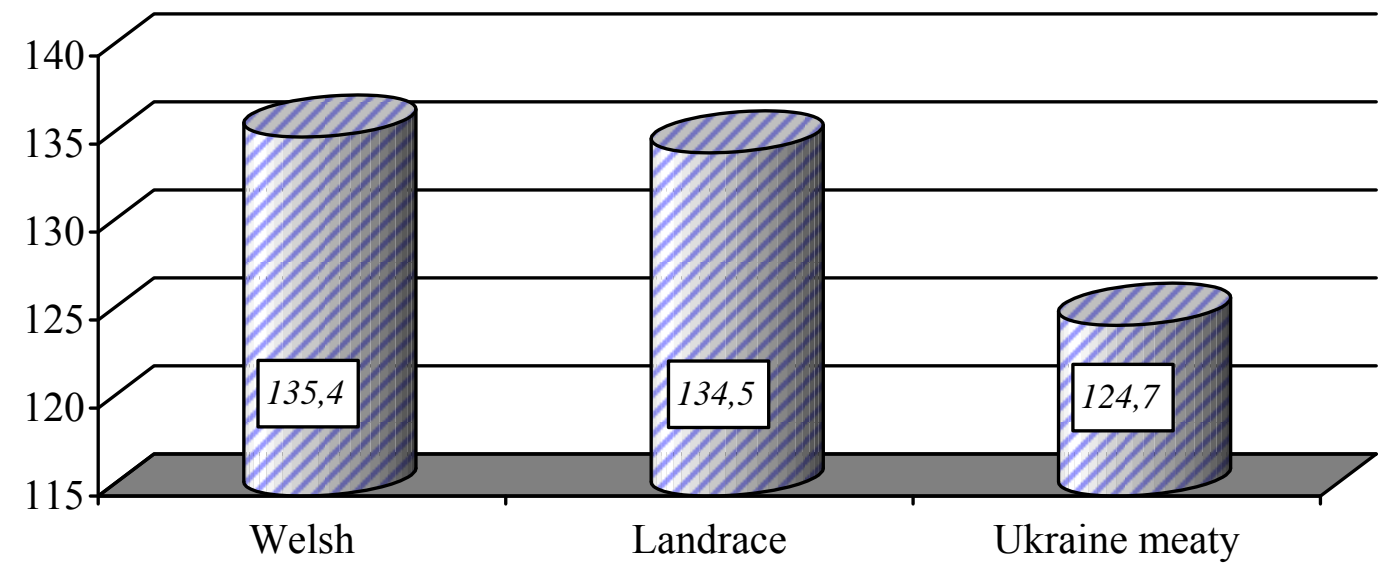

$\square$ Litter weight for all dams, $\mathrm{kg}$

Fig. 3. Litter weight at weaning (in terms of 45 days) for all dams by breeds in breeding farms in Kharkiv region

According to the calculation of the index SIRQS advantage of sows of Welsh breed is evident (Fig. 4).

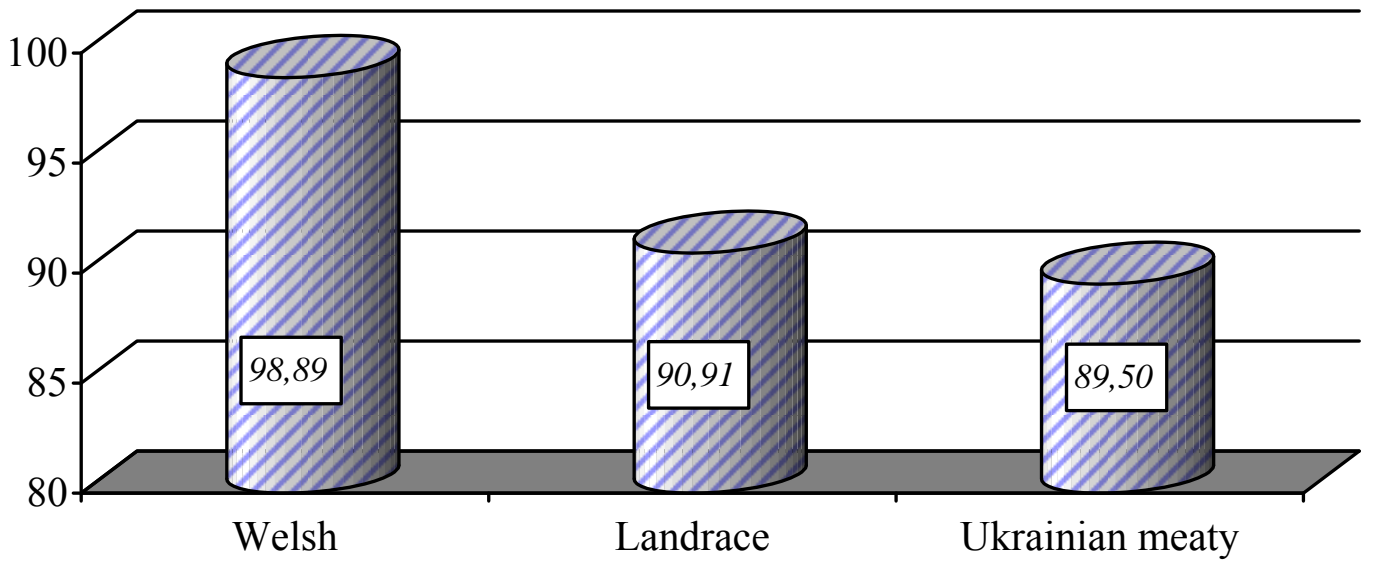

$\square$ Index SIRQS

Fig. 4. Index SIVYAS for all sows by breeds in breeding farms in Kharkiv region

For example, dams of Welsh breed for this trait had 8,07 points more compared to Landrace and 9.34 points more compared to sows of Ukrainian meaty breed of pigs.

\section{Conclusions}

Involvement the developed selection methods to the selection process ensured improving reproductive capacity of sows of the national population of Wales breed, that was reflected later on the status of this breed for its main localization in Ukraine.

The results of evaluation of the genetic potential of productivity and degree of its realization indicate that with increasing its level for the studied traits the degree of its realization decreases. Accordingly, this points to the need to apply in practice certain technological approaches that will promote improving the degree of realization of the genetic potential of productivity. 


\section{References}

1. Agapova Je. M. Teoretychni aspekty i praktyka udoskonalennja porid svynej $v$ Ukrai'ni $/$ Je. M. Agapova, R. L. Susol, I. Je. Tkachenko // Metodologija naukovyh doslidzhen' z pytan' selekcii', genetyky ta biotehnologii' u tvarynnyctvi. Materialy naukovo-teoretychnoi' konferencii'. Chubins'ke, 25 ljut. 2010.- K.: Agrarna nauka, 2010.- S. 19-20.

2. Tserenyuk O.M. Modyfikacija importnogo genetychnogo materialu v Ukrai'ni: monografija. IT UAAN. Harkiv.-2010.-248s.

3. Halak V.I. Produktivnost' svinej razlichnyh genotipov i urovnja stresschuvstvitel'nosti N.I. Halak // Problemy povyshenija jeffektivnosti proizvodstva zhivotnovodcheskoj produkcii: tez. dokl. mezhdunar. nauch. - prakt. konf. (12 - 13 okt. 2007 g.) - Zhodino: Nauch. - prakticheskij centr NAN Belarusi po zhivotnovodstvu, 2008. - S. $141-143$.

4. Rybalko V. P. Selekcija ta gibrydyzacija u svynarstvi / V. P. Rybalko, V. P. Burkat. - Kyi'v, BMT, 1996. $-144 \mathrm{~s}$.

5. Chalyj O.I. Pidvyshhennja rivnja vidtvornoi' zdatnosti svynomatok porody uel's / O.I. Chalyj, O.M. Cerenjuk, V.P. Shablja, O.V. Akimov // Problemy zooinzhenerii' ta veterynarnoi' medycyny: zbirnyk nauk. prac'.-vypusk 32.-Chastyna 1.-HDZVA.-Harkiv.-2016. - S. 89-96.

6. Basovskij N.Z. Ocenka geneticheskogo potenciala molochnoj produktivnosti u krupnogo rogatogo rogatogo skota / N.Z. Basovskij // Citologija i genetika. - 1991. - T.25. - №3. - S. 57 - 61.

7. Kovalenko V.P. Metody ocinky genetychnogo potencialu i kontrolju selekcijnyh procesiv u tvarynnyctvi N.P. Kovalenko, T.I. Nezhlukchenko// Tavrijs'kyj naukovyj visnyk.-Herson.-Ajlant.-Vyp. 64.2008.-S. 143-149.

8. Tserenyuk O. M. Efektyvnist' selekcijnyh i ocinnyh indeksiv materyns'koi' produktyvnosti svynej / O. M. Tserenyuk, A. I. Hvatov, T. A. Stryzhak // Nauk.-tehn. bjuleten' № 102 / NAANU, In-t tvarynnyctva. H., 2010. - S. 173 - 181.

9. Patent na korysnu model' № 100641 Ukrai'na, MPK A01K 67/02 Sposib vidboru svynomatok / Tserenyuk O. M.; Instytut tvarynnyctva NAAN. - № u 201411117; zajavl. 13.10.2014; opubl. 10.08.2015. - Bjul. №15. $-3 \mathrm{~s}$.

10. Plohinskij N. A. Rukovodstvo po biometrii dlja zootehnikov / N. A. Plohinskij. - M. : Kolos, 1969. $352 \mathrm{~s}$

11. Merkur'eva E.K. Biometrija v selekcii i genetike sel'skohozjajstvennyh zhivotnyh. - M.: Kolos, 1970. - 423s.

12. Patent na korysnu model' № 97393 Ukrai'na, MPK A01K 67/02 Sposib vidboru stresostijkogo remontnogo molodnjaku / Tserenyuk O.M.; Instytut tvarynnyctva NAAN. - № u 201411118; zajavl. 13.10.2014; opubl. 10.03.2015. - Bjul. №5. - 3 s. 